\title{
COMIMENTS
}

\section{First Amendment Standards for Subsequent Punishment of Dissemination of Confidential Government Information}

In interpreting the first ainendment, the judiciary often faces a conflict when the issue involves "government information," i.e., information within the government's control or custody, including closed hearings and ineetings. ${ }^{1}$ On one side of the conflict is the public's interest in obtaining government information that is relevant to participatory democracy. The countervailing consideration is the sovereign's interest in keeping certain government information confidential; ${ }^{2}$ legitimate government functions can be seriously harmed if such inforination is disseminated. To resolve fairly the conflict between these two interests the judiciary must create a system of review that will maintain some confldentiahty while allowing enough informed discussion to prevent the misuse of power and permit effective self-government. Some form of restraint or penalty must therefore be available to hinder dissemination of sensitive government information.

Prior restraints on publication are of only limited use in this regard. Largely because they too thoroughly deter speech that later may be found desirable, ${ }^{3}$ prior restraints must meet strimgent constitutional standards to be upheld. ${ }^{4}$ Even when allowable, prior restraints are often ineffective in curbing dissenination since the government frequently does not learn of a planned article im tinne to stop its publication with an injunction. ${ }^{5}$ Thus, subsequent punishinent laws-statutes

1. For a fuller definition of government information, see Comment, The Public's Right of Access to Government Information Under the First Amendment, 51 CHI.-KENT L. REv. 164, 165-67 (1974).

2. For a brief discussion of government interests in this area, see Comment, Government Information Leaks and the First Amendment, 64 CALIF. L. Rev. 108, 111-13 (1976).

3. Nebraska Press Ass'n v. Stuart, 427 U.S. 539, 559 (1976).

4. New York Times Co. v. United States, 403 U.S. 713,714 (1971).

5. The publication of the details of a hydrogen bomb design in September 1979 provides a good illustration. The government won a preliminary injunction against The Progressive earlier in the year that prohibited the magazine from publishing an article, compiled from docuinents in public libraries, describing low a hydrogen bomb works. TIME, Apr. 9, 1979, at 69. Another author then drafted a similar piece. The government won injunctions against two California 
that provide for punishment after dissemination-remain the primary method of protecting confidential government information.

The United States Supreme Court's solution to the government information problein has been to uphold subsequent punishment of "insiders" 6 who leak ${ }^{7}$ unauthorized information but to leave the press free to publish virtually anything that falls into its hands. ${ }^{8}$ In Landmark Communications, Inc. v. Virginia, ${ }^{9}$ the Court held that the first amendinent prohibits criminal prosecution of persons who publish truthful information about secret judicial review commission hearings, so long as those publishers are not involved in the hearings. The Court stated that "the substantive evil must be extremely serious and the degree of imminence extremely high" 10 before subsequent pumshment of "outsiders" who publish confidential government information will be permitted. By employing this "imminent danger" test the Court implied that it will use the same strict test of constitutionality regarding subsequent punishment of speech as it has with prior restraint. ${ }^{11}$ The Court inade clear, however, that it generally will uphold prior restraint orders or criminal statutes barring releases of information concerning govern-

newspapers, the Peninsula Times Tribune and the Daily Californian, enjoining thein from publishing the second article, but failed to win an imjunction agamst the Madison, Wisconsin, Press Connection before publication took place. The government then lifted the earlier injunctions. TIME, Oct. 1, 1979, at 82.

6. "Insiders" are people who have legitimate access to confidential government information. Government employees fall into this category, as do witnesses and attorneys who are participants in at least partially confidential hearings. See, e.g., Nebraska Press Ass'n v. Stuart, 427 U.S. 539, 601 n.27 (1976) (Brennan J., concurring). "Outsiders" are those wlio do not have such access, eg., the press.

7. Leaks are disclosures of government information outside the official communication channels. Unauthorized leaks are those involving officially confidential mforination. Comment, supra note 2, at 109-10. Throughout this discussion "leak" is used to indicate an unauthorized leak.

8. Landınark Communications, Inc. v. Virginia, 435 U.S. 829 (1978). The Landmark approacli focuses on the status of the disseminator rather than the form of restraint: subsequent punishment statutes and prior restraints are both subjected to rigid tests when directed at outsiders, but are both given lenient scrutiny when aimed at leakers. This insider/outsider dichotomy has some merit because the government requires a certain loyalty from its einployees to function well; the press, on the other hand, needs more freedom to fulfill its role as investigator of government actions.

9. Id. The Landmark case arose wlien the Virginian Pilot, a Landinark newspaper, published a piece that aceurately described a pending inquiry by the Virgimia Judicial Inquiry and Review Commission and named the judge whose actions were being investigated. Landmark was then prosecuted for violating a Virginia statute making it unlawful to divulge the identity of a judge who was the subject of a Commission investigation. Id. at 831 . The case was tried by a judge, and Landmark was fonnd guilty and was fined $\$ 500$ plus prosecution costs. The Virginia Supreme Court affirmed the conviction, noting that no prior restraint was involved and concluding that the Commission could not function properly without criminal sanctions protecting its confidentiality. Id. at 822-23. The United States Supreme Court, following the Bridges v. California imminent danger test, 314 U.S. 252, 263 (1941), reversed and remanded. 435 U.S. at 845.

10. 435 U.S. at 845 .

11. See text accompanying notes $60-66$ infra. 
ment hearings by participants and government employees. ${ }^{12}$

This Comment will argue that the Supreme Court's scheme for protecting confidential government information is ill-conceived in that it will inhibit revelation of government abuse of power. The near total freedom to publish government infornation accorded the press will not ensure that government malfeasance will be reported. Because of the Court's holding that journalists cannot legally refuse to answer grand jury questions regarding their sources, ${ }^{13}$ the Court's plan to uphold liberally those statutes punishing government information leakers will greatly discourage disclosure of government abuses. This result can be avoided by fashioning a fairly strict constitutional review standard for statutes that prohibit "insiders" from revealing government information.

Furthermore, Landmark's application of the imminent danger test to statutes forbidding "outsiders" from disseminating government infornation will prevent the government from deterring publication of inforination that is likely to cause substantial harm and provide little or no benefit. As noted already, the imminent danger test is, in effect, as stringent as the test employed for prior restraints. The rigidity of the imminent danger test may ultimately cause the Court, when confronted with speech that creates serious but not imminent danger, to lower its review standards, thus chilling even political speech that involves no government inforination. Since subsequent punishinent statutes offer greater procedural safeguards and more opportunities to inount constitutional challenges than do prior restraints, statutes pumishing publication of confidential government infornation can be safely reviewed with a standard less strict than the imminent danger test, assuming that the easier standard protects the public's interest in acquiring government information useful for self-government.

In short, the Court's treatment of confidential government information is flawed because it is not tailored to protect dissemination of information necessary to advance the public's interest in self-governnent while allowing the government to prevent publication of confidential information not necessary to that interest. This Cominent proposes a first aniendment approach that more nearly fits the self-government interest because it creates protection for leakers in some instances and reduces the current protection for outsiders when they dissemmate confidential information. ${ }^{14}$

12. See text accompanying notes 24-30 infra.

13. Branzburg v. Hayes, 408 U.S. 665 (1972).

14. Although these two proposed changes are intended to be implemented together as part of a unified scheme, the arguments for each are independent. Thus, even if the Court refuses to 
I

\section{The CONFlicting InTERests of GOVERnMENT AND THE} Public in the Free SpeEch Area

The first amendment has three primary purposes. One is to protect individual autonomy and human dignity by allowimg individuals to voice freely their thoughts and behefs. ${ }^{15}$ Another purpose is to preserve the marketplace of ideas; theoretically, truth will be discovered when all ideas can be presented freely. ${ }^{16}$ The final purpose of the first amendment is to protect effective self-government, since speech must be free if citizens are to participate intelligently in democracy. ${ }^{17}$

In the area of "pure" pohtical speech-pohitical speech not imvolving confidential government information-all three of these public interests are present. ${ }^{18}$ The government's interest in this area, on the other hand, is restricted basically to preventing serious breaches of civil order, such as riots. As a result, in most cases concernmg pure political speech the public's interests will decisively outweigh the government's.

Where speech concerning confidential governunent information is concerned, however, the interests involved are quite different. The autonomy and marketplace interests, already adequately protected in the pure pohitical speech area, need no further protection here. No one can seriously claim that his autonomy is infrimged because he cannot freely broadcast confidential government information. Nor can a convincing argument be unade that confidential government information is needed to prevent distortion in the marketplace of political ideas-assuming that the category of confidential government information is not unreasonably large. Thus, the only public interest that is involved with speech concerning confidential governinent information is the interest in self-government. ${ }^{19}$ While neither the press nor the public has an

accord leakers any first amendment protection, the review standards for outsiders who publish confidential government information nonetheless slould be modified.

15. See Blasi, The Checking Value in First Amendment Theory, 1977 AM. B. Found. RESEARCH J. 521, 544-45.

16. Id at 548-49. Professor Blasi notes that perhaps the best argument for the marketplace of ideas is that, while admittedly imperfect, the system inhibits the search for truth less than any other system. Id. at 550 .

17. Id. at 554-57.

18. Relatively unfettered political speech obviously is necessary if the markctplace of idcas and democratic government are to function effectively. Because political beliefs frequently are among the most passionate beliefs that people hold, government punishment of political speech also cuts particularly hard into individual autonomy and human dignity.

19. Alexander Meiklejohn argues that the first amendment should be interpreted to allow citizens access to all information useful to self-government. Meiklejohn, The First Amendment $1 \mathrm{~s}$ an Absolute, 1961 SUP. CT. REv. 191, 255. Some support for this position can be found in Red Lion Broadcasting Co. v. FCC, 395 U.S. 367, 390 (1969), where the Court noted that "[t]he right of the public to receive suitable access to social, political, esthetic, moral, and other ideas and experiences . . . may not constitutionally be abridged . . . ." 
absolute right of access to government information, ${ }^{20}$ this general "informed self-government" interest carries significant weight. Moreover, the public has a narrower and stronger interest in procurimg governinent information when it concerns abuses of power; the Supreme Court is more likely to prefer this subset of the broader self-governinent interest when there is a conflict with the government's interest in confidentiality. ${ }^{21}$

The government, on the other hand, has an interest in addition to maintaining order when it seeks to keep certain government information confidential: ensuring the effectiveness of legitimate government functions. These functions can be seriously harmed if confidential information is disseminated. For example, disclosure of investigative files might forewarn a violator and allow him to escape arrest or indictment. Similarly, publication of certain economic information, such as a Securities and Exchange Commission decision to suspend trading in a certain corporation's stock, might provide some parties with an unfair advantage if released early. Revelation of the proceedings of legitimately confidential ${ }^{22}$ government hearings or meetings might disrupt decisionmaking, smce officials might then be afraid to air their true views. $^{23}$ Finally, dissennination of defense secrets might cause loss of hives or endanger national security.

In short, the public's and the government's interests in speech imvolving confidential government information are more evenly matched than are their respective interests in pure pohtical speech, where the pubhic's interests almost always outweigh the government's. Thus, the Court should devise-and has devised-constitutional review standards that allow almost no infringement of pure political speech by the government. In cases concerning government inforination, however, the Court should employ a different approacl that preserves substantial confidentiality while simultaneously permitting enough informed discussion to allow effective self-government and to check abuse of power.

20. Houchins v. KQED, 438 U.S. 1 (1978). In Houchins, a broadcasting company was denied access to a notoriously wretched portion of a county jail. With two justices not participating, the Court ruled 4-3, including Justice Stewart's concurring opinion, that " $[t]$ his Court has never intimated a First Amendunent guarantee of a right of access to all sources of information within government control." Id. at 9. Justice Stewart agreed as to this point. Id. at 16.

21. Blasi, supra note 15 , at 558-59.

22. The issue of what information can appropriately be labeled "classified," while important, is beyond the scope of this Comment.

23. Comment, The Constitutional Right to Know, 4 Hastings Const. L.Q. 109, 146 (1977). 


\section{The CUrRent Approach: No Protection For INFORMATION LEAKERS}

While the Landmark case itself did not involve prosecution of "insiders" who leaked government information, ${ }^{24}$ it is apparent that the Court generally will allow subsequent punishment of information leakers. The Court exphicitly approved the use of prior restraints against those involved in confidential government proceedings who divulge information about that activity: "[M] uch of the risk [of injury to the State's interests] can be eliminated through careful internal procedures to protect the confidentiality of Commission proceedings." 25 In support, the Court cited Justice Brennan's concurring opinion in $\mathrm{Ne}$ braska Press Association v. Stuart; ${ }^{26}$ Brennan had stated that trial judges could legitimately eniploy injunctions to bar and then punish statenients by lawyers, parties, witnesses, court officials, and law enforcenient personnel. ${ }^{27}$ Since the Landmark Court endorsed this use of prior restraints against information leakers, it seeins certain that subsequent punishment of thein will be approved; a prior restraint certainly infringes on first ainendment rights no less than does subsequent punishment. Moreover, Justice Stewart, in his concurring Landmark opinion, explicitly supported criminal sanctions: "I find nothing in the Constitution to prevent Virgima fron [criminally] punishimg those [excepting newspapers] who violate this [review commission's] confidentiality."28 Fimally, generally upholding statutes aimed at leakers would coinport with an earlier Supreme Court case, Sheppard v. Maxwell, ${ }^{29}$ where the Court stated that cities and counties could pass ordmances prohibiting dissemination of inforination about criminal cases by their enuployees. The Court, then, obviously beheves that the leaking of government information is one of those "certain forms of speech . . . [that] has been considered outside the scope of constitutional protection." 30

By itself, the Landmark schene for protection of government information would be clunisy but not unreasonable. Establishing tough review standards for statutes covering outsiders while allowing criminal sanctions agamst leakers will bring at least some government wrongdoing to print while offering some protection to government information.

24. The Court emphasized that "we do not have before us any constitutional challenge to a state's power to keep the Commission proceedings confidential or to punish participants for breach of this mandate." 435 U.S. at 837.

25. Id. at 845 .

26. Id.

27. 427 U.S. 539, 601 n.27 (1976) (Brennan, J., concurring).

28. 435 U.S. at 849 (Stewart, J., concurring).

29. 384 U.S. 333, 362 (1966).

30. Konigsberg v. State Bar, 366 U.S. 36, 50 (1961). 
Because of the risk of punishment, government enuployees will divulge confidential information only if they have strong incentives to do so; substantial government misconduct at times will provide sufficient motive. Once the press has the information, however, high subsequent punishment standards will allay publishers' fears that publication of the information will lead to criminal sanctions. Since the press is free to publish whatever information it can unearth, journalistic mvestigation is encouraged.

This systein is far from perfect, however. It is not tailored specifically to deter publication of confidential information that has no value for self-government, nor does it greatly encourage government employees to divulge government information concerning abuses of power. Moreover, a system that nuust grant outsiders almost total publication freedom in order to ensure the dissemination of information useful for self-government will reliably reveal government misconduct only if the press can keep its sources of information secret. Assuming that only reporters had this right, then leaks to the press would not, as a practical nuatter, usually be prosecuted. Leaks to nonmedia parties, on the other hand, would be punished. This scheme would give reasonable protection to the first amendment aim of promoting self-government: leaks to third parties tend to be made for personal gain - to repay an obligation, to aid a friend, or to increase the leaker's income-while leaks to the press tend to convey information useful for self-government, although sometimes they admittedly are used as political weapons.

Unfortunately, the integrity of this scheme was undercut by the Court's earlier decision in Branzburg v. Hayes. ${ }^{31}$ There the Court stated it could not "seriously entertain the notion that the First Amendment protects a newsman's agreeinent to conceal the criminal conduct of his source or evidence thereof." ${ }^{32}$ Because reporters thus may be forced to divulge their sources when crime is involved, the existence of valid criminal statutes punishing leakers of government information will reduce reports of government abuses: while the press will not be punished for articles revealing confidential government information, prosecutors will threaten reporters with contenipt if leakers are not identified. At least some would-be leakers will be deterred by the threat of future unmasking, which could not only destroy their careers but might also lead to criminal conviction.

Of course, as the Branzburg holding becomes well-known, information leakers inay use anonymous methods of disbursing their information. Some reporters also have been willing to go to jail rather than

31. 408 U.S. 665 (1972).

32. Id. at 692 . 
reveal their sources. ${ }^{33}$ Moreover, many leakers apparently have such strong motives for their acts that they are willing to run the risk of being identified. ${ }^{34}$

Not all leakers are so strongly motivated, however. In addition, publishers greatly prefer to seek out two or three confirmations before publishing an item. Confirmers often demand anonymity because they intend to remain in government; they are unlikely to have strong enough incentives to see the information im print to risk criminal punishinent. ${ }^{35}$ Where there are copies of documents this reluctance may not inatter, but where the press must rely on oral accounts, it may not be possible to procure the requisite confirmation. Since it is unlikely that the Branzburg decision will be overruled or modified, ${ }^{36}$ it is clear that if a lement approach to "leaker statutes" is maintained, governinent abuses of power nay not be disclosed when they should be.

\section{III}

\section{Methods of EXEMPTing "Whistleblowers" From Punishment}

If, as the Landmark Court stated, the Virginian Pilot's publication of the judge's name "clearly served those interests im public scrutiny and discussion of governmental affairs which the First Amendment was adopted to protect," ${ }^{37}$ then the leaking of that type of inforination should have some constitutional protection. To achieve this result, some way of protecting the "whistleblower"-the einployee who divulges government waste or abuse of power-is needed. The Court should therefore interpret the first annendment to require that convictions of leakers ineet a significant constitutional review standard. This requirement would be based not so much on the imsider's first amendinent rights as on the public's first amendment rights to receive at least enough government inforination to check abuse of power.

\section{A. The Inadequacy of Traditional First Amendment Tests}

The tests traditionally used to protect speech cannot be used to review leaker statutes, since they fail to provide adequate protection for

33. TIME, Oct. 30,1978 , at 66 .

34. $I d$.

35. Id.

36. Since Branzburg, the Court has pursued a policy of treating the press and the public alike for first ameudment purposes. See, e.g., Houchins v. KQED, 438 U.S. at 11 (citing Saxbe v. Washington Post Co., 417 U.S. 843, 850 (1974); Pell v. Procunier, 417 U.S. 817, 834 (1974); Branzburg v. Hayes, 408 U.S. 665,684 (1972)). In this atmosphere even a modification of Branzburg seems highly improbable.

37. 435 U.S. at 839. 
either public or governmental interests. The imminent danger test utilized with outsider statutes could not be used, as the government would then have no effective way to protect its legitimate interests in keeping soine information confidential. As will be discussed nore fully below, that test-which requires an extreinely imminent and extreinely serious danger before speech can be punished-can only rarely be inet.

On the other hand, soine form of ad loc balancing test-which weighs the interests of the particular parties before the court ${ }^{38}$-would not sufficiently protect speech that reports government abuse. There are at least two inherent probleins with using an ad hoc balancing test. ${ }^{39}$ First, such a test would not provide enough certainty as to whether a particular leak would be protected. Except in extreine circumstances, a would-be whistleblower could not be sure of the result the Court would reach in applying the test. All but the most courageous employees would thus be deterred from speaking. ${ }^{40}$

The second problein is that, because an ad hoc balancing test involves weighing the interests before the Court in the particular case, strong public opinion will sometimes determine the outconie of the test. ${ }^{41}$ The test requires that the interests of the specific parties be assigned a value; the Court cannot help but be influenced by any existing public passion in assigning these values. Dennis v. United States ${ }^{42}$ provides an excellent example. There the Court, using an ad hoc balancing test, ${ }^{43}$ upheld the defendants' convictions for trying to organize the Communist Party of the United States. The outcoine clearly was influenced by the anti-Communist hysteria sweeping the nation, ${ }^{44}$ yet one of the first anrendment's primary purposes is to protect unpopular political speech.

A definitional balancing test-where the general interests in a given area of law are balanced ${ }^{45}$ - provides far better protection than does ad hoc balancing because the former forces the Court to determine the value of particular categories of speech. Unpopular speech will be protected when it falls within a category that the Court feels should be exempt froin punishinent, since the only alternative would be

38. Nimmer, National Security Secrets $v$. Free Speech: The Issues Left Undecided in the Ellsberg Case, 26 StAN. L. Rev. 311,329 (1974).

39. Nimmer, The Right to Speak from Times to Time: First Amendment Theory Applied to Libel and Misapplied to Privacy, 56 CALIF. L. Rev. 935, 939-41 (1968).

40. See Kalven, The New York Times Case: A Note on "The Central Meaning of the First Amendment," 1964 SuP. CT. REv. 191, 212; Nimmer, supra note 39, at 939.

41. Nimmer, supra note 39 , at $939-41$.

42. 341 U.S. 494 (1951).

43. Id. at 510 .

44. J. Nowak, R. Rotunda, \& J. Young, Handbook on Constitutional Law 734 (1978).

45. Nimmer, supra note 38 , at 329. 
to declare that category unprotected by the first amendment. Definitional balancing is not particularly useful in reviewing government $\mathrm{m}$ formation statutes, however, because the test is too rigid; convictions of all leakers of information in an unprotected category are upheld, regardless of special circumstances. The government's imterests im confidentiality in a given category of government information may generally outweigh the interests justifying a leak. In some circumstances, however, a leak of information in that category would be justified by government malfeasance. Generally, for example, FBI files must be kept confidential to keep from tipping off those bemg investigated. Convictions for leaks of this material slrould therefore generally be upheld. When the FBI abuses its role and uses its mvestigatory power to harass those with unpopular political views, however, leaks of that behavior slould not be punished.

One way to avoid the rigidity problem would be to employ a subjective review standard, i.e., one that takes imto account the msider's state of mind. For example, one approach is to grant first amendment protection to leaks when the leaker, in good faith, believed the benefit of communicating the information to the public outweighed any harmful consequences. ${ }^{46}$ However, it is extremely difficult to ascertam a leaker's state of mind. Moreover, because the public's right to imformation necessary to clieck government abuse is the primary imterest to be protected in this area, the leaker's state of mind should not determme whether the leak is punishable. The issue is the harm and benefit to society that a particular leak entails; the individual's motives and beliefs as to those harms and benefits are irrelevant.

\section{B. A Proposed Solution: The "Substantial Abuse" Test}

This dilemma could be resolved by the establishment of an objective, two-part test: if a reasonable person would think the leaked government information demonstrated substantial abuse of power, then the leaker could not be punished unless the dissemination created extreine imminence of extreme danger-in other words, unless the imminent danger test is satisfied. The leak would be unprotected unless the first test was met. Having met that hurdle, the leak would be shielded unless the second, stricter test were also satisfied.

Under this system, a government employee could not be convicted for leaking confidential papers showing that the executive branch had violated a statute prohibiting military incursions into neutral countries in the absence of exigent circumstances or a declaration of war, simce a reasonable person would believe that a substantial government abuse

46. For an unusual version of this type of test, see Comment, supra note 2, at 141-42. 
of power had occurred. An employee involved in a confidential judicial review commission hearing, however, would be convicted if he revealed testimony that a judge being investigated had demanded and received free coffee from a local cafe for himself and his married mistress. Since the abuse of power was slight, it would not justify revelation of the judge's personal life. ${ }^{47}$ Of course, the Securities and Exchange Commission employee who tipped off a stock broker that a particular issue was about to be suspended from trading would have no constitutional defense at all. Because the information does not concern abuse of power, the speech would not be protected by the first amendment.

Note that the defense is not and should not be absolute, because there are occasions when revelation of the abuse would carry grave consequences. Imagine, for exainple, a CIA employee leaking the name, location, and goal of a United States spy in Iran who is part of a plan that violates the CIA charter. Assuming that a statute forbade disclosure of that information, such a revelation would be pumshable. Given the hostility in Iran towards the United States and the Iranian citizens' current propensity for violence, the leak would create extreme imminence of an extremely serious evil.

By protecting leaks only where the infornation reveals substantial abuse of government power rather than in the broader case where the infornation is significantly useful for self-government, the "substantial abuse" test provides necessary protection for the government while protecting the public's strongest self-government interests. The government requires a certain loyalty from its employees and froin participants in confidential proceedings in order to function effectively. A self-government trigger would exempt so much leaking from punishment that government functions such as decisionmaking would be significantly disrupted. The narrower substantial abuse test, however, would have a negligible impact on government functions because it would protect far fewer leaks. Any damage to government functions caused by these leaks would be more than offset by the public's extreinely strong interest in discovermg government abuse.

The substantial abuse test has the additional advantage of allowing punishment for leaks made purely for personal benefit or partisan pohtical reasons. It also permits pumishment in circunistances where the harm is particularly great. In effect, the test creates a crude

47. While the Landmark Court merely assumed, without deciding, that states have a legitimate interest in keeping judicial review commission hearings confidential, 435 U.S. at 841 , the Court's enumeration of the practical reasons for confidentiality indicated that it considers the practice constitutional. $I d$. at 835-36. Of special note is the fact that judges are much more likely to retire or resign when confronted with private, rather than public, charges. $I d$. 
balancing mechanisin without encountering the subjectivity of ad hoc balancing or the inflexibility of definitional balancing. The test is also not dependent on the leaker's state of mind.

One objection to the test that might be offered is that there is no consensus as to what constitutes abuse of power. The danger is that, as in the ad hoc balancing test apphed in Dennis, the test may be too easily manipulated to reach a desired result. As Professor Blasi has illustrated, however, when one considers specific elements of government misconduct there is more of a consensus than might at first seem apparent:

Is there a viable concept of official "misconduct" that does not simply collapse into "unwisdoin" or "unpopularity"? Behavior in violation of the applicable criminal code sucl as embezzlement or the acceptance of a bribe might provide a starting point for such a concept. Behavior adjudicated to be unconstitutional could also be considered misconduct without collapsing the distinction . . . . The category could also be extended to include serious misrepresentations inade to other institutions of government or to the general public. In addition, employinent of the powers of office to augment one's private wealth, even if not technically illegal, could be considered misconduct. ${ }^{48}$

While not exhaustive, this hist could at least serve as the foundation for an abuse of power construct that would not be undesirably plastic.

\section{IV}

\section{Problems with Using the Imminent Danger Test to Protect Publication of Confidential GOVERNMENT INFORMATION}

The Landmark Court, of course, did not adopt a review standard for government infornation leakers that would protect whistleblowers. Instead, the Court sought to encourage that "scrutimy . . . of government affairs which the First Amendment was designed to protect" 49 by establishing an extrenely tough review standard for statutes punishing the publication of government information. The Court's discussion of the standard to be applied was perplexing. Chief Justice Burger, writing for the Court, first questioned the relevance of the clear and present danger test. ${ }^{50}$ Later, he expressly applied the test in his analysis. ${ }^{51}$ More importantly, the Chief Justice cited conflicting formulations of the test without explaining which version should be used.

The clear and present danger test has gone through three distimct

48. Blasi, supra note 15 , at 543 .

49. 435 U.S. at 839 .

50. Id. at 842 .

51. Id. at 845 . 
phases since its inception. ${ }^{52}$ In the first stage-approximately 1937 to 1951 - the Court's position was that "the substantive evil inust be extremely serious and the degree of imminence extreinely high before utterances can be pumshed."53 This is the imminent danger test. During the Cold War years, the clear and present danger test was greatly diluted: it involved balancing the seriousness and probability of the evil against the desirability of the speech. ${ }^{54}$ Finally, beginning about 1966 , the Court revitalized the test ${ }^{55}$ by holding that the state cannot "forbid or proscribe advocacy of the use of force or of law violation except where such advocacy is directed to inciting or producing imminent lawless action and is likely to incite or produce such action."56

While Landmark contains conflicting language, ${ }^{57}$ apparently the Chief Justice meant the imminent danger test to control. ${ }^{58}$ Thus, the government can win a conviction only if it shows that an extreme imminence of extreme danger was present. Moreover, "a solidarity of evidence. . . is necessary to make the requisite showing of imminence."

52. J. NowAK, R. RotUnda, \& J. Young, supra note 44, at 728-40. The start of each phase is marked, respectively, by Herndon v. Lowry, 301 U.S. 242 (1937); Dennis v. Umited States, 341 U.S. 494 (1951); Bond v. Floyd, 385 U.S. 116 (1966).

53. Bridges v. California, 314 U.S. 252, 263 (1941).

54. Dennis v. United States, 341 U.S. 494, 510 (1951). There is a great difference between the Bridges imminent danger test and the Dennis balancing test. The imminent danger test requires a high probability of a serious evil. The balancing test requires only a low probability of a serious evil. J. Nowak, R. Rotunda, \& J. Young, supra note 44, at 735.

55. J. Nowak, R. Rotunda, \& J. Young, supra note 44, at 739-40.

56. Brandenburg v. Ohio, 395 U.S. 444,447 (1969) (per curiam).

57. In Landmark, Chief Justice Burger first stated that the test requires a court to weigh "the immmence and magnitude of the danger said to flow from the particular utterance . . . against the need for free and unfettered expression." 435 U.S. at 843 (emphasis added). This is clearly the Cold War balancing formulation. Note that there is no requirement that the danger be serious or the immineuce extreme. Yet, two pages later the Chief Justice wrote that "the substantive evil must be extremely serious and the degree of imminence extremely high before utterances can be punished." Id. at 845 . In other words, courts are also to apply the conflicting "imminent danger" test.

58. The balancing formulation was stated in a section of the opinion designed to reinforce the concept that the courts, not the legislature, are to determine whether the speech created a clear and present danger. $I d$. at $842-44$. Moreover, the only case cited near the tribute to balancing is Pennekamp v. Florida, 328 U.S. 331, 334 (1946), a case that employed the imminent dauger test. Fimally, any use of the imminent danger test tends to obviate the balancing test. If the government can prove that there was an extreine imminence of extreme danger, it is almost certam that the danger would outweigh the need for free speech in the particular instance.

It is possible that the Court intends the balancing test and imminent danger tests to be used in two different stages, with the desirability of speech to be weighed against the danger it created only if the danger is extremely serious and its degree of imminence is extremely high. This interpretation of Landmark seems strained, however, since the tests are mentioned in different places in the opinion and in different contexts. Moreover, for purposes of this Comment, it makes hittle difference whether the Court intended to create such a two-stage test; the two-stage test would be even tougher than the unadorned imminent danger test and this Comment will argue that the latter is already too strict.

59. 435 U.S. 105 (1973). The Court has taken this requirement quite seriously in other cases. 
Note that the Landmark imminent danger test has the same effect as the strict standard used in prior restraint cases. In a per curiam opinion in New York Times Co. v. United States, ${ }^{60}$ the Court held that the government "carries a heavy burden of showing justification for the iniposition of such a [prior] restraint." The Court also stated that "any prior restraint on expression coines to this Court with a heavy presumption' against its constitutional validity,"61 a rule the Court has applied in other recent prior restraint cases. ${ }^{62}$ The Landmark holding, by requiring the government to prove an extremely high degree of imminence of an extreinely serious danger, creates in effect the saine constitutional standard; any prior restraint voided by the New York Times standard would, if recast as a subsequent punishment statute, also be found unconstitutional. This interpretation is supported by the Court's recent opinion in Smith v. Daily Mail Publishing Co. ${ }^{63}$ There the Court, drawing heavily on Landmark, stated: "Whether we view the statute as a prior restraint or as a penal sanction for publishing lawfully obtained, truthful information is not dispositive because even the latter action requires the highest form of state interest to sustain its validity."64

This, of course, is an extrennely tough test. As the Court noted a few sentences later in Daily Mail: "Our recent decisions demonstrate that state action to punish the publication of truthful information seldoin can satisfy constitutional standards."65 Furthermore, Justice Brennan noted in his concurring opinion in Nebraska Press Association v. Stuart:

In New York Times Co. v. United States, . . . we specifically addressed the scope of the "military security" exception . . . and held that there could be no prior restraint on publication of the "Pentagon Papers"

In Hess v. Indiana, 414 U.S. 105 (1973), the Court considered the constitutionality of a conviction for disorderly conduct. During an antiwar demonstration, the defendant liad yelled out: "We'll take the fucking street later," immediately after the police had cleared the street. The trial court found, and the Indiana Supreme Court agreed, that the remarks were imtended to imcite riotous beliavior and were likely to do so. The Supreme Court reversed in a per curiam opmion, stating that:

[A]t worst [Hess' words] amounted to nothing more than advocacy of illegal action at some indefinite future time. This is not sufficient to pernit the state to punish Hess' speech. Under our decisions, "the Constitutional guarantees of free speech and free press do not permit a state to forbid or proscribe advocacy of the use of force or of law violation except where such advocacy is directed to inciting or producing imminent lawless action and is likely to imcite or produce such action."

Id. at 108. If the imminence requirement was not met in Hess, it is a tough requirement indeed. 60. 403 U.S. 713, 714 (1971) (quoting Organization for a Better Austim v. Keefe, 402 U.S. $415,419(1971))$.

61. Id.

62. See, eg., Southeastern Promotions, Ltd. v. Conrad, 420 U.S. 546, 558 (1975); Organization for a Better Austin v. Keefe, 402 U.S. 415, 419 (1971).

63. 47 U.S.L.W. 4824 (1979).

64. Id. at 4825 .

65. Id. 
despite the fact that a majority of the Court beheved that release of the documents, which were classified "Top Secret-Sensitive" and which were obtained surreptitiously, would be harmful to the Nation . . . 66

Since Landmark implied-and Daily Mail confirmed-that the current subsequent punishment test is the same as the prior restraint test when outsiders are involved, it is almost certain that even subsequent punishment of a newspaper for such a publication would not be allowed now by the Court.

The problein is that this constitutional standard is too stiff for subsequent punishment statutes involving confidential government inforination, especially where there is httle or no social benefit to be gained froin publication. In many instances-unless the Court adulterates the imminent danger test - the government will not be able to deter harmful dissemination of legitimately confidential information because protective statutes cannot ineet the "extremely high imminence of an extremely serious danger" requirement. Consider a variation on the controversy surrounding The Progressive inagazine when it threatened to pubhish an article describing how to build a hydrogen bomb. ${ }^{67}$

Assume that the inagazine decided not to warn the government of publication so that it would run no risk of being enjoined. Also, assume the information would be valuable in building the device and that it was kept only in government offices. In these circumstances, even if Congress had previously passed a statute forbidding publication of such information, the government probably could not show imminent danger, since only a foreign government would have the massive amount of inoney and expertise needed to build the device, and even then construction would take years. ${ }^{68}$

In the actual Progressive case a United States district court judge issued an injunction, ${ }^{69}$ apparently solely because of the potential for

66. 427 U.S. at 591-92 (Brennan, J., concurring). The passage goes on to state, however, that the publication "might [have been constitutionally] prosecuted . . . as a violation of various espionage statutes." Id. Brennan apparently thought subsequent punishment would be treated differently from prior restraint, a theory the Court has now rejected.

67. TIME, Mar. 19, 1979, at 29.

68. N.Y. Times, Sept. 18, 1979, at A1, col. 6. For exainple, note the following excerpt: [T] he building of a hydrogen bonib is not a task that could be undertaken without vast mdustrial and scientific resources.

....

... [A] hydrogen bonb would clearly seem to be far beyond the reach of any terrorist group, however ample its resources.

Obtaining the needed naterials alone would be a dauntimg problent.

....

The construction of the bonb [also] involves an immensely conplex engineering system in which exact dimensions and geometry spell the difference between success and Id. failure.

69. Time, Apr. 9, 1979, at 69. 
serious harm. It is doubtful that the Supreme Court would have upheld that injunction, however, if it followed the Landmark holding. The district court judge seemed to be applying the Cold War ad hoc balancing test, where an extremely serious danger can offset the lack of imminence and thus allow either prior restraimt or subsequent punishment. ${ }^{70}$ The imminent danger test endorsed by Landmark, however, requires that both "the substantive evil must be extremely serious and the degree of imminence extremely high before utterances can be punished." 71

The danger, then, with employing the imminent danger test for dissemination of confidential government information is that when the Court is confronted by a situation similar to the Progressive case-that is, where there is great danger but not extreme imminence-the Court inay lower the imminence requirement to allow pumshment. Because the Court has applied the imminent danger test to all dissemination by outsiders regardless of whether government information was involved, any reduction in the imminence requirement would endanger freedon of pure political speech. ${ }^{72}$ Thus, paradoxically, maimtaining the tough imminent danger review test for statutes protecting confidential government information may im the long run lead to less protection for pure political speech.

\section{V \\ LOWERING REVIEW STANDARDS FOR SUBSEQUENT PUNISHMENT OF OUTSIDERS}

Use of the imminent danger test in reviewing subsequent punishment of outsiders might be justified if that were the only way to protect adequately the public's first amendment interests. It is here that the distimction between pure political speech and "government information" becomes important. It would be dangerous to employ a more lement review standard for subsequent punishment statutes barring dissemination of pure political speech, smce this would infrimge on desirable speech. Statutes barring dissemination of confidential government information, lowever, could be reviewed with an appropriate standard less stringent than the imminent danger test without significantly deterring desirable dissemination.

Aside from preventing speecli that creates an "extreme immimence

70. J. NowaK, R. RotUNDA, \& J. Young, supra note 44, at 735.

71. 435 U.S. at 845 (quoting Bridges v. California, 314 U.S. 252, 263 (1941)).

72. For an example, see Dennis v. United States, 341 U.S. at 494, where the government upheld the defendants' convictions under the Smith Act for conspiring to organize the Communist Party of the United States. The Court decided that the evil involved-the possible overthrow of the government by force-was so grave that the consequence did not have to be very immiment for the punishments to be upheld. Id. at 509-11. 
of an extreme danger," the government does not have any interest in preventing pure political speech. At the same time, the public has a great interest in such speech; protecting pure pohtical speech preserves individuality, the marketplace of ideas, and effective self-government. Because the public's interests are so strong and the government's are so weak in this area, the imminent danger test should be maintained even if the restraining inechanism is a subsequent pumshment statute rather than a prior restraimt.

On the other hand, where government information is concerned, the government has a particularly strong interest in confidentiality, albeit one that seldoin could meet the harsh Landmark test. The citizens' interest is limited to ensuring effective participatory democracy and only a subset of that interest-correcting government abuse-consistently outweighs the government's interests. Since dissemination of government information often should be deterred, the Court's decision to scrutinize all subsequent punishment statutes covering outsiders as closely as prior restraints went further than was wise in protecting disseinination. Subsequent pumshment statutes have intrinsic safeguards that are lacking in prior restraints; statutes barring dissemination of government information by outsiders can therefore be subjected to a lesser review standard without compromising the public's interests. This approach would be particularly safe if the Court provided some first amendment protection to whistleblowers as proposed.

\section{A. Safeguards Inherent in Subsequent Punishment Statutes}

Clearly the Court wants speech only rarely restramed; that is evident from the requirements the Court has established for prior restraints. There are three methods the Court has chosen to protect speech frow overbearing prior restraimts. First, as already seen, the Court has established a strict standard of review for prior restraint of speech: in each case the government must overcome a heavy presumption against the constitutionality of the restraint. ${ }^{73}$ Second, the Court has encouraged persons involved to challenge the constitutionality of prior restraints before they have a harmful effect. The Court has held, therefore, that once a prior restraint has been granted, prompt judicial review inust be available. ${ }^{74}$ Finally, the Court has required that procedural safeguards be met before prior restraints can be granted. Thus, for example, the Court has dissolved ex parte orders banning rallies when no showing was made that notifying the opposing parties and giving them an opportunity to participate was impossible. ${ }^{75}$ More gen-

73. New York Times Co. v. United States, 403 U.S. at 714.

74. Southeastern Promotions, Itd. v. Conrad, 420 U.S. at 560.

75. Carroll v. President \& Comm'rs of Princess Anne, 393 U.S. 175, 180 (1968). 
erally, the Court has held that a prior restraint "avoids constitutional infirmity only if it takes place under procedural safeguards designed to obviate the dangers of a censorship system."76

With regard to the last two of these three methods, subsequent punishment statutes inherently meet tougher standards than the Court requires of prior restraints. In particular, these statutes encourage more challenges to government restraints on speech than do prior restraints. Subsequent punishment statutes also afford procedural safeguards greater than those the Court has required for prior restraints. For these reasons, a standard of review less strict than the one used for prior restraints could be applied to subsequent pumishment statutes covering government inforination without encouraging encroachment on desirable speecl.

Froin the publisher's point of view there is a crucial difference between prior restraints and subsequent punishment statutes: the certainty of punishment. The "collateral bar rule" prevents a party who disobeys a court order froin defending against resulting conteinpt charges by arguing that the order was unconstitutional or erroneous. ${ }^{77}$ A publisher faced with a restraining order knows he definitely will be held in conteinpt if he violates it. Subsequent punishment statutes, lowever, allow the publisher to weigh the importance of publishing against a risk of punishment rather than against the burden of the certain punishment that prior restraint imposes. In other words, under a subsequent punishment statute the pubhisher will consider not only the penalty itself but also the constitutionality of the statute and its popular support when considering publishimg restricted inforınation. ${ }^{78}$

When the message to be published is not "time bound," i.e., when swift dissemination is immaterial, this difference between prior restraint and subsequent punishment is inconsequential, since the publisher faced witl a prior restraint will inerely delay publication until he can appeal the order and receive adequate determination of its constitutionality. In a deinocratic government, however, even a delay of a day or two in publication nray be crucial. ${ }^{79}$ The problems with a restraining order given just prior to elections are obvious. More generally, "dainage can be particularly great when the prior restraint falls upon the communication of news and commentary on current

76. Southeastern Promotions, Ltd. v. Conrad, 420 U.S. at 559 (quoting Freedınan v. Maryland, 380 U.S. 51,58 (1965)).

77. Barnett, The Puzzle of Prior Restraint, 29 Stan. L. Rev. 539, 552-53 (1977). For an amazing example of the collateral bar rule in action, see Walker v. City of Birmingham, 388 U.S. 307 (1967).

78. See A. Bickel, The Morality of Consent 61 (1975).

79. Carroll v. President \& Comm'rs of Princess Anne, 393 U.S. at 182.

80. Nebraska Press Ass'n v. Stuart, 427 U.S. at 559. 
events." $"$ Public opinion is often permanently formed on a given event, person, or topic within a matter of a few weeks or even a few days. Publications delayed until after public opinion has been set or public interest has waned may lose the impact they would have had. It is in this way that prior restraint is more chilling than subsequent punishment. $^{81}$

Subsequent punishment statutes also entail procedural safeguards stronger than those the Court has mandated for prior restraints. It is far easier for the government to obtain a prior restraint than to prosecute someone for violating a speecli statute. Under a subsequent punishment statute, a prosecutor must weigh the time, energy, and expense a prosecution will take. ${ }^{82} \mathrm{He}$ also must consider the political consequences of bringing charges, the procedural safeguards afforded a criminal defendant, and the likelihood that the evidence will convince a jury to return a guilty verdict. ${ }^{83}$ A prosecutor is therefore likely to act only if he feels punishment of the speech is relatively important.

Subsequent punishment also provides better safeguards against erroneous suppression by giving the defendant publisher the option of a jury trial. Frequently, juries act as checks on government abuse of power ${ }^{84}$ Administrators with restraining powers and even judges issuing injunctions may tend to overvalue the government's interest in restricting speech; juries have a less self-interested view. Judges and administrators may also hold personal prejudices that influence their restraining decisions. Jurors, because of their diversity and number, are less subject to personal caprice.

Subsequent punishment further offers the protections of a criminal trial: the government has the burden of proof, the standard for conviction is high, ${ }^{85}$ cross-exainination is permitted, and there are restrictions

81. Traditionally, subsequent punishments have been thought to limit speech less because "a prior restraint ... has an immediate and irreversible sanction. [A] threat of criminal or civil sanctions . . . 'chills' speech, [but] prior restraint 'freezes' it." Nebraska Press Ass'n v. Stuart, 427 U.S. at 559. The idea seems to have been that with subsequent punishment statutes there is a sanction only after publication has taken place, and therefore the publisher can disseminate the message if he is willing to accept later punishment, whereas prior restraint completely prevents publicatiou.

This analysis is faulty, however. Since the United States government does not physically prevent printing or distribution when it has secured a restraining order, the publisher may proceed if he is willing to accept the punishment, ie., a contempt of court citation. Thus, in practice, with both prior restraints and subsequent punishment statutes punishment cones only after publication. Barnett, supra note 77, at 550-51.

82. Enrerson, The Doctrine of Prior Restraint, 20 L. \& Contemp. PRob. 648, 657 (1955).

83. Times Film Corp. v. Chicago, 365 U.S. 43, 75 (1961) (Warren, C.J., dissenting).

84. Emerson, supra note 82, at 657. Admittedly, jurors will tend to protect popular speech and censor unpopular expression such as obscenity or extreme political statements. Even so, criminal sanctions are preferable because a defendant can always elect to be tried by a judge alone. Note, Freedom of Speech, Press and Association, 85 HARv. L. Rev. 199, 208 (1971).

85. The standard of proof for criminal trials is "beyond a reasonable doubt"; for injunctive 
as to what may be imtroduced as evidence. Some or all of these eleinents may be missing im injunction-granting courts. Although the Supreme Court has established procedural safeguards for prior restraints, they are not nearly as strong as those required for criminal trials. ${ }^{86}$ Finally, im criminal cases the government, because of fifth amendment double jeopardy restrictions, has no right to appeal. The government's right to appeal mjunctive cases is limited only by res judicata. ${ }^{87}$

There are, then, sliarp differences between prior restraints and subsequent pumshments of speech. Subsequent pumshment statutes necessarily offer greater procedural protections against government suppression and also better encourage publishers to challenge government decisions that certam speech sliould be prohibited. Subsequent punishment statutes that cover confidential government information can therefore be reviewed witl a suitable standard less strict than the imminent danger test witlout mcreasing unwarranted government suppression.

\section{B. Using a "Political Relevance" Test for Outsiders who Disseminate Confidential Information}

While statutes punishmg outsiders for disseminating confidential information can safely be reviewed by a test less strict than the imminent danger test, any proposed test must provide a fair amount of protection for the public's self-government interests. A two-stage test soniewhat similar to the proposed abuse of power test for insiders would provide such protection while avoiding the shortcomings of the traditional tests discussed earlier. The proposed test is that if a reasonable person would consider the particular information clearly relevant in formulatimg political opinions, the publication would be constitutionally protected unless it created an extreme imminence of extremely serious danger.

Political relevance seems to be the ideal trigger for constitutional protection since the public's only legitimate first amendment imterest when confidential information is mvolved is effective self-government.

actions the more lenient "clear and convincing proof" standard is einployed. J. NOWAK, R. RoTUNDA, \& J. YOUNG, supra note 44, at 742.

86. Apparently the only specific procedural requirements that prior restramts must meetoutside of the notification requirement for ex parte orders mentioned in the text accompanying note 75-are those listed in Southeastern Promotions, Ltd. v. Conrad, 420 U.S. 546, 560 (1975):

First, the burden of mstituting judicial proceedings, and of proving that the material is unprotected, must rest on the censor. Second, any restraint prior to judicial review can be imposed only for a specified brief period and only for the purpose of preserving the status quo. Third, a prompt final judicial determmation must be assured.

87. J. NowaK, R. RotUNDA, \& J. Young, supra note 44, at 742. 
By itself, however, the notion of political relevance is too vague to constitute a practical test; a guideline is needed. A workable guideline could be that any confidential information concerning (a) abuse of power, (b) waste, incompetence, or inefficiency, or (c) decisionmaking or government actions should almost always be considered politically relevant. These categories provide a core for the definition of political relevance. Thus, most confidential governunent information necessary for participatory deunocracy would be protected, but technological details largely would not. The government, however, could still punish dissemination of pohitically relevant information whenever the imminent danger test was inet. And it could protect even nondangerous pohitically relevant information by punishing most leakers, who are protected only when revealing abuses of power.

This "political relevance" test would eliminate the "How to Build an H-Bonib" type of problein in cases where the information had hittle or no self-governinental value. If the article included details of hydrogen boinb design, its publication could be punished because that inforination would not influence a reasonable person's political opinions. On the other hand, publication of a transcript of a statutorily confidential Department of Energy ineeting that revealed the government had inadvertantly allowed confidential reports contaming hydrogen bounb instructions to be placed in public libraries would clearly be constitutionally protected.

One argument against employing the proposed political relevance test for statutes punishing outsiders who disseminate governinent information is that soine articles that should be published might remain uncirculated because of fear of punishment. Despite the guidelines suggested, the protective trigger is soinewhat vague; there would therefore be occasions when a publisher would be deterred from publishing because he could not tell whether the Court would decide that a reasonable person would consider the information relevant in formulating his political views. However, at least this uncertainty would occur only with regard to governinent information that was of dubious political significance; any time government information became clearly politically important, dissemination would be strongly protected.

Note that the political relevance test gives Congress very hittle incentive to expand the category of confidential information. One advantage of the Landmark approach is that it gives Congress no incentive at all for such expansion. The press can be punished for publication only when the imminent danger test is met, whether or not confidential governunent information is involved. The danger of proposing a review standard for confidential information that is substantially less strict than the one for pure political speech is that the legislature will be 
tempted to restram publication of government information that the public may want by classifying such information as confidential. The political relevance test, however, will almost always reach the same result as the imminent danger test. Thus, Congress could not further restraim the press by proclaiming additional government information to be confidential. Of course, expansion of the confidential information category will deter dissemination because of the penalties for leakers, but the political relevance test will not provide any added motivation for such expansion.

\section{CONCLUSION}

The Landmark decision crystallized the Court's scheme for protecting confidential government information through the use of subsequent pumshment. Insiders are to be accorded no first amendment protection against confidentiality statutes, but statutes forbidding the dissemination of government information by outsiders are to be tested by the imminent danger test. Because of the Court's Branzburg decision requiring reporters to reveal their sources durmg grand jury imvestigations, the number of reports by insiders concerning government abuse of power will decrease significantly. To prevent this, the Court should institute a two-part objective review test: if a reasonable person would think that the leaked information concerned substantial government abuse, the leak would be constitutionally protected unless it created extreme imminence of an extremely serious evil. This test achieves a crude balancing of interests without suffering from the uncertainties of ad lioc balancing or the inflexibility of definitional balancing.

On the otlrer liand, the extremely tough imminent danger test that the Landmark Court applied to subsequent purishment statutes concerning outsiders will not protect confidential information even though publication causes serious harm and provides little or no self-government benefit. The Court's choice of the imminent danger test showed that-witlr regard to outsiders-it will treat subsequent pumshment and prior restraints identically. Subsequent punishment statutes, however, offer inore opportunities for constitutional challenges and greater procedural safeguards than do prior restraints. While a standard less strict than the imminent danger test might chill desirable pure pohtical speech, the government and public interests are more evenly matched when the confidentiality of government information is at stake. Thus, a more lenient review standard could safely be used with subsequent punishment of publication of government information. The Court slould therefore. hold that dissemination of confidential governinent information by outsiders is constitutionally protected if a reasonable 
person would consider the particular information clearly relevant in forming his political opinions, and if dissemination would not create an extremely imminent danger of an extrennely serious evil. Although this test might create soine uncertainty as to whether publication of an article could be punished, information that was clearly pohtically signifcant could be published without fear of punishment.

Bruce E. Methven*

* A.B. 1974, University of California, Berkeley; third-year student, Boalt Hall School of Law. 